Г. Г. Кульсарина. Отражение башкирско-монгольских языковых связей в лексике башкирского фольклора

Научная статья

УДК 811.512.141

DOI: 10.18101/2305-459X-2020-4-151-158

\title{
ОТРАЖЕНИЕ БАШКИРСКО-МОНГОЛЬСКИХ ЯЗЫКОВЫХ СВЯЗЕЙ В ЛЕКСИКЕ БАШКИРСКОГО ФОЛЬКЛОРА
}

\author{
(C) Кульсарина Гульнур Галинуровна \\ доктор филологических наук, старший научный сотрудник, \\ Уфимский федеральный исследовательский центр Российской академии наук \\ Россия, 450054, г. Уфа, пр-т Октября, 71 \\ kulsarina.g@mail.ru
}

\begin{abstract}
Аннотация. Словарный фонд фольклорных текстов богат и разнообразен. Он включает всю совокупность средств башкирского языка, в том числе диалектных и заимствованных. Большой пласт лексики фольклорных произведений составляют, безусловно, общеупотребительные слова в своем прямом значении, которые активно используются как в устной, так и в письменной речи. Нейтральные слова и выражения способствуют тому, чтобы фольклорные тексты стали общепонятными и подлинно народными. В то же время в народных текстах активно употребляются создающие своеобразный стиль и поэтику фольклорного произведения диалектизмы, фразеологизмы, мифологизмы и заимствовавания. На протяжении всей истории своего существования контакты тюркских языков с другими языками мира привели к обогощению словарного состава языков за счет заимствований и калькирований. Башкирский язык не стал исключением. В нашей работе мы рассматриваем отражение башкирско-монгольских языковых связей в языке текстов башкирского народного творчества, исходя из семантического разряда провели их классификацию.

Ключевые слова: башкирско-монгольские параллели; монголизмы; башкирское народное творчество; этимология; этнолингвистика.
\end{abstract}

\section{Для цитирования}

Кульсарина Г. Г. Отражение башкирско-монгольских языковых связей в лексике башкирского фольклора // Вестник Бурятского государственного университета. Язык. Литература. Культура. 2020. Вып. 4. С. 151-158.

Язык башкирского народного творчества всегда был в центре внимания исследователей. Если фольклористы обращались к нему при изучении стиля и поэтики произведений устного творчества, то языковеды приводили примеры из фольклорного текста в качестве иллюстративного материала для подтверждения своих положений по истории, лексикологии и синтаксису башкирского языка. В отличие от художественных и публицистических произведений, фольклорные тексты представляют собой стабильный источник, отражающий общенародный обиходный язык. Известный тюрколог Дж. Г. Киекбаев, определяя развитие башкирского литературного языка, отметил: «В процессе развития литературных языков и в становлении их норм, в изучении истории развития литературного языка, несомненно, народный язык может стать основой, потому что современный башкирский язык своими корнями, по сути, сплетается с башкирским народным языком, и лексико-грамматические орфографические 
нормы литературного языка заложены в народном языке» [10, с. 20]. Наибольшую актуальность в современной науке приобретает изучение лексикосемантических, морфологических, стилистических и поэтических особенностей текстов фольклора, предполагающее не только выявление стиля народных текстов, но и определение факторов, обусловливающих данную специфику, в частности базовых стилевых черт фольклорного текста. На формирование лексических особенностей фольклорного текста большое влияние имел целый комплекс факторов, среди которых основные - это общественная роль фольклора, коллективный характер народного творчества, влияние коммуникативного акта в условиях естественной коммуникации, особенности фольклорной идейно-эстетической макросферы, характеризующейся специфическим способом эстетического освоения действительности, основным критерием которого является соответствие традиционной культурной норме, идеалу. «Словарный фонд башкирских фольклорных текстов богат и разнообразен. Он включает всю совокупность средств башкирского языка, в том числе диалектных и заимствованных. Большой пласт лексики фольклорных произведений составляют, безусловно, общеупотребительные слова в своем прямом значении, которые активно используются как в устной, так и в письменной речи. Нейтральные слова и выражения способствуют тому, чтобы фольклорные тексты стали общепонятными и подлинно народными» [12, с. 244]. В то же время в народных текстах активно употребляются создающие своеобразный стиль и поэтику фольклорного произведения заимствовавания, на изучение которых в данной статье делается основной акцент.

О фольклорной семантике писали многие ученые. По справедливому утверждению А. Т. Хроленко, «на характер языка фольклора влияют многие факторы, в том числе и факторы многоязычности населения той или иной территории» [14, с. 87]. На протяжении всей истории своего существования контакты тюркских языков с другими языками мира привели к обогащению словарного состава языков за счет заимствований и калькирований. Слова, общие для башкирского, монгольских и тунгусо-маньчжурских языков, впервые были изучены профессором Дж. Г. Киекбаевым в научном труде «Основы исторической грамматики урало-алтайских языков» [9, с. 10]. В монографии «Историческое развитие лексики башкирского языка» профессор Э. Ф. Ишбердин отмечает: «Предварительное сравнение общих для тюркских и монгольских языков лексических единиц показывает, что из тюркских языков башкирский, татарский, казахский, киргизский, каракалпакский и в своеобразной форме чувашский стоят обособленно по степени усвоения монгольских слов. Кроме общих для всех тюркских языков монголизмов, в указанных языках имеются явные заимствования, видимо, более поздние, из монгольского и калмыкского языков» [8, с. 33]. О том, что в этногенетическом процессе башкир активное участие принимали и монгольские племена, свидетельствуют исследования диалектолога Н. Х. Максютовой. «Нет сомнений, что этноним сальют монгольского происхождения», - пишет ученый. Сохранившиеся названия родовых подразделений племени сальют, орагый, орхан, мэркэт, шумыр, шуMblx генетически возводятся к названиям монгольских племен и родов [13, 
Г. Г. Кульсарина. Отражение башкирско-монгольских языковых связей в лексике башкирского фольклора

c. 173]. В последние годы в башкирском языкознании появились работы А. Г. Вахитовой посвященные башкирско-монгольским языковым связям на материале лексики [7].

Анализируя общие лексические единицы в башкирском и монгольском языках на примере текстов башкирского народного творчества, мы выделили несколько критериев, способствующих выявлению заимствований. Основным моментом является совпадение звуковой оболочки и семантики соответствующего башкирского слова с монгольским при условии отсутствия этого слова в древнетюркском, при ограниченном его распространении в современных тюркских языках, системе башкирских говоров и широком бытовании в монгольских языках. По итогам нашего исследования мы выделили следующий список башкирских и монгольских общих лексических единиц, встречающихся в текстах башкирского народного творчества, - это слова, обозначающие явления природы, метеорологические явления, гидрографические и орографические явления, части тела человека, животных, растений и т. д.

Первая лексико-семантическая группа - названия, обозначающие явления природы. Например, башкирское «бозъ» - монгольское «мес(ен)» (лед), башкирское «монар» (мгла, дымка, иней) - монгольское слово «манан» (туман), башкирское «көрт» - монгольское «хер» (сугроб), башкирское «кырау» - монгольское «хяруу» (иней), башкирское «буран» (буран, метель, буря) - монгольское «бороо(н)» (дождь), башкирское «кырпак» (кар) - монгольское «хармаг» (первый снег, пороша). Примеры из башкирских фольклорных текстов: Йәш хәтер ташка яззан, карт хәтер бозъа яздан (букв. 'Молодая память на камне высечена, старая — на льду') [15, с. 351]; Шар кар, боз hыммак hыуылк була. Шува күрә лә ува «карбоз» тип исем бирәләр. (букв. 'Шар был холодным, как снег и лед. Поэтому его назвали «карбозљ” (кар (снег) + боз (лед) [6, с. 321]; Кырпак кар төшөугә эзен юzалта (букв. К снежной пороше теряет след) [1, с. 210]; Матур сәскәне кырау тиз ала (букв. 'Красивые цветы заморозкам первыми поддаются') [15, с. 356].

Во вторую группу собрали названия гидрографических и орографических явлений. Например, башкирское слово «дала» - монгольское слово «тал(а)» (степь, поле), башкирское «туғай» (луг) - монгольское «токой» (локоть, часть руки от локтя до кисти; излучина, изгиб, лука (реки), башкирское «уба» (холм, курган) - монгольское «овоо(н)» (груда, куча, курган), «обон» (возвышенность, насыпь), башкирское «диңгез» - монгольское «тэнгэс/тангис» (море), башкирское «тулкын» - монгольское «долгио(н)» (волна, вал), башкирское «үззән» (русло (реки), долина) — монгольское «уса(н)» (вода, река), башкирское «аклан» (поляна) - монгольское «аглаг» (безлюдное место, пустынная местность), башкирское «ер» - монгольское «шорой» (земля, почва), башкирское «кая» - монгольское «хад(ан)» (скала, утес), башкирское «тау» (гора) - монгольское «таг» (плоская вершина горы, плато) и др. Общие для тюркских и монгольских языков лексические единицы: башкирское «йылға» (река) - монгольское «жалга» (овраг, сухое русло), башкирское «тупрак» (почва, земля) - монгольское «тоброг/товрог» (пыль, прах). Примеры: Донъя яратылгас та, кешеләр төрлө ерзә ил короп, йәшәй башлавандар (букв. 'Когда 
был создан мир, все люди в разных местах земли начали жить, построив свои государства') [4, с. 142]; Тау каяһыз булмай, бөркөт ояһыз булмай (букв. 'Нет горы без камня, нет орла без гнезда') [15, с. 169]; Ир күрке - мал, Үзән күрке тал (букв. 'Долину украшает ива, а мужчину - его скот)'; Тилегә диңзгез тубыктан (букв. Дураку море по колено) [15, с. 371]; Үлемһез̧ донъя юк, үтелгеһез йылга юк (букв. 'Без смерти нет мира, нет реки, которую нельзя переплыть’) [15, с. 521]; Якшылькк кылып диңгез̧гә ташлаһаң̧ да кайтыр (букв. 'Доброе дело, даже брошенное в море, вернется') [15, с. 280]; Ерле халык элгәре ул тауга менергә курка (хәүефләнә) торвайны: томан эсенән кеше күзенә ниндәйзер имәнес йән эйәләре күренер булган, ти. Бигерәктә ундавы Сарыкташ тигән кая кешеләрз̧е куркыуга һалган (букв. 'Раньше местные жители боялись подниматься на эту гору: там, говорят, людям мерещилось чтото страшное. Страх на людей особенно наводила скала Сарыкташ’) [6, с. 71].

В следующую группу мы отнесли лексические параллели, относящиеся к небесной сфере, которые этимологизируются по языковым данным обоих языков. Например, башкирское слово «күк» (небо) - монгольское «хех / хухэ» (синий, голубой, зеленый, серый; смуглый, темный (о цвете лица), башкирское «тәнре» (небо, всевышний) - монгольское «тэнгэр» (небо, небеса, гром, всевышний, бог) и др. Примеры из текстов народного творчества: Якщы менән яман apahbl - ер менән күк араһы (букв. 'Между хорошим и плохим расстояние от неба до земли’) [15, с. 651]; Бер күктә ике ай булмай, бер күңелдә ике мөхәббәт булмай (букв. 'В одном небе не бывает две луны, одна душа не вмещает две любви') [15, с. 438]; Тәңре ува бер угыл биргән (букв. 'Всевышний дал ему одного сына') [5, с. 207].

В четвертой группе мы собрали лексику, которая относится к названиям отрезков времени. Например, башкирское слово «сак» (время, пора) монгольское «цаг» (период, время, срок); башкирское «иртә» - монгольское «эрт(эн)» (рано, ранний, раньше, утром), башкирское «йыл» - монгольское «жил» (год), башкирское «кис» (вечер) - монгольское «кечи» (раньше, давно), башкирское «төш» (полуденное время) - монгольское «дули» (середина (дня, ночи)), башкирское «төн» (ночь) - монгольское «туне» (темный). Приведем примеры из башкирского фольклора: Иртә торвандың гүмере озон (букв.'Кто рано встает, тот долго живет’) [15, с. 257]; Яззыци бер көнө йылды туйзыра (букв. 'Один день весны год кормит') [15, с. 643]; Уны кис менән сызыл hыззъыртhаң, пәрейзәр йыйылалар (букв. 'Если выйдешь вечером и свистнешь, соберутся пэри') [5, с. 130]; Кеше күңеле - караңңды төн (букв. 'Душа человека - темная ночь') [15, с. 440]; Шунан һун ул, кистәрзән бер кис балаларын сыуал янына йыйнап альл, былай тип һөйләгән... (букв. 'После этого в один из вечеров он собрал своих детей возле чувала и вот что сказал...') [6, с. 395]; Төн уртакайында йүгереп сыктым, / Туганай, йөрәккәйгенәм, / Келәт бауы сылтыраванда (букв. 'Выбежал в полночь, Туганай, душа моя, услышав звон амбарной веревки') [2, с. 237]; Хан иртә менән вәзирен ебәреn, Kapaca батырзарзы сәйгә сакыра (букв. 'Хан рано с утра отправляет визиря пригласить Караса-батыра с друзьями на чай’) [5, с. 131]. 
Г. Г. Кульсарина. Отражение башкирско-монгольских языковых связей в лексике башкирского фольклора

Пятая группа - это названия, относящиеся к анатомии человека и животных: башкирское слово «танау» (нос) - монгольское «танага» (носовая перегородка), башкирское «кабырға» - монгольское «хабирга» (ребро, бок), башкирское «һакал» - монгольское «сахал» (борода, усы), башкирское «бүтәгә» - монгольское «бетеге» (зоб птицы), башкирское «кауырһын» монгольское «гуурс(ан)» (перо птичье), башкирское «маңлай» (лоб) монгольское «магнай/манлай» (лоб, передовой, лучший, глава, вождь, головной), башкирское «койка» - монгольское «хуйх» (опаленная кожа), башкирское «арка» (спина, хребет) - монгольское «ар(а)» (спина, зад, задняя спина), башкирское «беләк» (предплечье) - монгольское «билэ» (запястье), башкирское «бил» - монгольское «бэлхуус» (талия), башкирское «боғазљ» (горло; глотка) - монгольское «богорла» (перерезать горло, задушить» (тюркское «богаз/богуз» (горло, глотка), башкирское «быуын» (сустав) монгольское «бугуй» (предплечье), башкирское «йөз̧» (лицо, лик) монгольское «зус(эн)» (вид, внешность) / монгольское «нуур» (лицо), башкирское «йөрәк» - монгольское «зурх(эн)» (сердце), башкирское «колак» (ухо) - монгольское «хулхи» (внутреннее ухо, ушная сера), башкирское «аяк» (нога) - монгольское «адаг» (конец, устье), башкирское «кыл» (конский волос, щетина, шерсть) - монгольское «хялгас(ан)» (конский волос), башкирское «мөгөз» (рог) - монгольское «мегеес(ен)» (хрящ), башкирское «тояк» монгольское «туур/туурай» (копыто) и др. Примеры: Маңлайына язzан хак язмылттан / Касып кына котолоп булмайзыр (букв. 'От судьбы, что написана на лбу, не убежишь') [2, с. 207]; Үзе бер карыш - һакалы мең карыш (букв. 'Сам ростом в пядь, а борода в тысячу пядей' [1, с. 259]; Kapan торhалар, бына бер сак, ер тырнап үкереп, хандың ете йәшәр үгезе килеп сыва. Күзен кан басъкан, мөгөзө менән ерзе тишә, шул кәзәр ажарлана, күрһәң, котоң осорлок! Караса батыр килә ла, тегенең ике мөгөзөндн тотоп алып, өйрөлтөпөйрөлтөп сөйөп ебәрә, үгез һарай аша дыңк итеп барып төшә (букв. 'И вот однажды они увидели, как с диким ревом выбежал семилетний бык хана и землю копытами роет. Глаза у него залиты кровью, рогами землю пашет, сильно взбешен, увидишь - испугаешься! Подошел Караса-батыр и, взяв его за рога, два раза покрутил и подбросил вверх, бык пролетел через дворец и с грохотом упал') [5, с. 302]; Талдан вына нескә билдәреңде / Tалдырыпталдырып һөйгән дә йәр кайза (букв. 'Где возлюбленный твой, который бы любил твою талию, которая тоньше ивы') [2, с. 56]; Урал батыр тау башында озак торманы, ти: кес̧һһенән теге өс бөртөк кылды алып өтөүе булды Акбуззаттың каршыzа тып итеп килеп бас̧ыуы булды, ти (букв. 'Урал-батыр долго не стоял на этой горе: как только он сжег три конских волоса, Акбузат прискакал к нему') [5, с. 167]; Борон-борон борондан / Кеше мазар булмаван,/ Килеп аяк бассмаган, / Ул тирәлә коро ер / Барлывын һис бер кем белмәгән, / Дүрт явын диңзгез ураткан / Булван, ти, бер урын (букв. 'В древнюю пору, давным-давно, было, говорят, место одно, куда никто не ступал ногой. И на целом свете никто не знал, не ведал о суше той. С четырех сторон обступала это место морская вода' [3, с. 24]; Йөз картайhа ла, йөрәк картаймаһын (букв. 'Если даже лицо стареет, пусть сердце не стареет') [15, с. 260]; Ашаванда 
колавың һелкенһен, эиләгәндә йөрәгещ елкенһен (букв. 'Когда ешь, пусть уши шевелятся; когда работаешь, пусть сердце рвется’) [15, с. 89]; Ауыр эшкә беләк бар, кыйыу эшкә йөрәк бар (букв. 'Для тяжелой работы есть руки, для опасной (рискованной) работы есть сердце’) [15, с. 178]; Ата үлеY - арка hыныly, инә YлеY - бәzер итең hульу (букв. 'Смерть отца ломает спину, смерть матери убивает сердце') [15, с. 202].

Следующая лексическая группа - это названия частей растений: башкирское слово «ағас» (дерево) - монгольское «агч» (клен), башкирское «ботак» (ветвь) - монгольское «бута» (кустарник, заросли), «бут» (куст, заросль), башкирское «емеш» (плод, фрукт) - монгольское «жиме» (плод, плоды, фрукты), башкирское «кыяк» (лист злаковых и травянистых растений) - монгольское «хияг» (вострец, пырей), башкирское «орлок»монгольское «ур» (семя), башкирское «сәскә» - монгольское «цэцэг» (цветок, соцветие), башкирское «үлән» (трава) - монгольское «епен(г)» (осока), башкирское «һабак» (стебель, ботва) - монгольское «саваа» (палка, прут), башкирское «борсак»- монгольское «бурцаг» (горох, горошина), башкирское «тары» (просо) - монгольское «тариа(н)» (хлеб, зерно, урожай) и др. Примеры: Зур авастың күләгәһе лә киң (букв.'У большого дерева и тень большая') [15, с. 49]; Емеште аша, ботавын hындырма (букв. 'Плоды кушай, но ветку не ломай') [15, с. 197]; Сәскәһе койолгас емеше булыр (букв. 'Как выпадут цветы, появятся плоды') [15, с. 197]; Орлогона күрә емеше (букв. 'Каково семя, таков и плод') [15, с. 197]; Балтырzаны беләктәй, / hapнahbl курай еләктәй, / Йылгалары көмөштәй, / Борсавы тәмле емештәй, / Уралтау, Уралтау! (букв. 'Где борщевик (толщиной) в руку, где саранка, как малина, где реки, как серебро, где горох вкусен, как ягоды, Уралтау, Уралтау!') [3, с. 244]; Бер тарынан бутка булмай (букв. 'Из одного зернышка каши не сваришь') [15, с. 77]; Көнбавыш һабавы менән һатылмай (букв. 'Подсолнух со стеблем не продают') [15, с. 571], Авас та Үз нәселен Үз тирәһенә йыя (букв. 'И дерево собирает свой род вокруг себя') [4, с. 87].

Таким образом, многосторонние контакты башкирского народа с другими наложили отпечаток и на язык фольклора. Язык и стиль произведений башкирского народного творчества свидетельствуют о богатстве и разноообразии его лексического фонда, включающего в себя всю совокупность средств башкирского языка, в том числе и заимствованных. В данной работе исследуя лексический состав башкирского фольклора, мы внимание уделяли отражению башкирско-монгольских языковых связей в текстах народного творчества. История языка тесно связана с историей народа - носителя данного языка. Проблема сравнительно-исторического изучения лексики, общей для башкирского и монгольского языков, заслуживает особого внимания и требует дальнейшего развития. 
Г. Г. Кульсарина. Отражение башкирско-монгольских языковых связей в лексике башкирского фольклора

Литература

1. Надршина Ф. А. Башкорт халык ижады. IX том. Йомактар. Өфө; Китап, 2007. 416 б. = Башкирское народное творчество / гл. ред. Ф. Г. Хисамитдинова. IX том. Загадки. Уфа; Китап, 2007. 416 с.

2. Башкорт халык ижады. Бәйеттәр. Йырзар. Такмактар. Өфө. Башкортостан китап нәшриәте, 1981. 392 б. = Башкирское народное творчество. Песни, частушки / сост. М. М. Сагитов; гл. ред. К. Мэргэн.

3. Башкорт халык ижады. Эпос. III китап. Өфө: Башкортостан китап нәшриәте, 1982. 344 б. = Башкирское народное творчество. Эпос / гл. ред. Г. Б. Хусаинов.

4. Мингажетдинов М. Х. Башкорт халык ижады. Әкиәттәр. II китап. Тылсымлы героик әкиәттәр. Өфө: Башкортостан китап нәшриәте, 1976. 344 б. = Башкирское народное творчество. Волшебные героические сказки

5. Башкорт халык ижады. Әкиәттәр. III китап. Батырзар тураһындағы әкиәттәр. Өфө: Башкортостан китап нәшриәте, 1978. 352 б. = Башкирское народное творчество. Сказки о богатырях / гл. ред. Г. Б. Хусаинов.

6. Надршина Ф. А. Башкорт халык риүәйәттәре һәм легендалары. Автор төзөүсе Ф. А. Нәзершина. Өфө: Башкортостан “Китап” нәшриәте, 2001. 468б. = Башкирское народное творчество. Легенды и предания.

7. Вахитова А. Г. Башкирско-монгольские языковые связи (на материале лексики). Уфа: Гилем, 2009. 216 с.

8. Ишбердин Э.Ф. Историческое развитие лексики башкирского языка М.: Наука, 1986. 149 с.

9. Киекбаев Дж. Г. Введение в урало-алтайское языкознание. Уфа: Башк. кн. издво, 1972. $151 \mathrm{c.}$

10. Киекбаев Дж. Г. Лексика и фразеология современного башкирского языка. Уфа: Башкир. кн. изд-во, 1966. 275 с.

11. Киекбаев Дж. Г. Основы исторической грамматики урало-алтайских языков. Уфа: Китап, 1996. 354 с.

12. Кульсарина Г. Г. Национальная языковая картина мира в текстах башкирского фольклора: монография. Уфа: РИЦ БашГУ, 2017. 356 с.

13. Максютова Н. Х. Восточной диалект башкирского языка. М.: Наука, 1976. 292 c.

14. Хроленко А. Т. Семантика фольклорного слова. Воронеж: Изд-во ВГУ, 1992. $140 \mathrm{c}$.

15. Әхтәмов М. Х. Башкорт халык мәкәлдәре һәм әйтемдәре һүзлеге. Өфө: Китап, 2008. 774 б.

\section{REFLECTION OF BASHKIR-MONGOL LANGUAGE RELATIONS IN THE LEXIC OF BASHKIR FOLKLORE}

\section{(C) Gulnur G. Kulsarina}

doctor of Sciences in Philology, senior researcher at the Department of linguistics of the Institute of history, language and literature of the Federal state budgetary scientific institution Ufa Federal research center of the Russian Academy of Sciences

71 Oktyabrya Prospekt, Ufa, 450054, Russia

kulsarina.g@mail.ru

Abstract. The vocabulary fund of folklore texts is rich and diverse. It includes the entire set of means of the Bashkir language, including dialectal and borrowed ones. A large 
layer of vocabulary of folklore works are, of course, common words in their direct meaning, which are actively used both in oral and written speech. Neutral words and expressions help to make folklore texts comprehensible and genuinely popular. At the same time, dialectisms, phraseological units, mythologisms and borrowings that create a unique style and poetics of a folklore work are actively used in folk texts. Throughout the history of its existence, the contacts of the Turkic languages with other languages of the world have led to the enrichment of the vocabulary of languages through borrowings and tracing. The Bashkir language is no exception. In our work, we consider the reflection of Bashkir-Mongolian linguistic ties in the language of texts of Bashkir folk art, based on the semantic category we have classified them.

Keywords: Bashkir-Mongolian parallels, Mongolisms, Bashkir folk art, etymology, ethnolinguistics.

Статья поступила в редакиию 26.10.2020; одобрена после рецензирования 25.11.2020; принята к публикаџчи 24.12.2020. 